\title{
Increasing the Effectiveness of Investment Management by Introducing Corporate Governance in Joint-Stock Companies
}

\author{
Amonboev Mahammadsidik \\ Head of the Department, Faculty of Tourism, Tashkent State University of Economics, Uzbekistan
}

\begin{tabular}{|c|c|}
\hline & ABSTRACT \\
\hline $\begin{array}{l}2016 \text { Research Leap/Inovatus Services Ltd. } \\
\text { All rights reserved. } \\
\text { DOI: } 10.18775 / \text { jibrm.1849-8558.2015.45.3001 } \\
\text { URL: } \underline{\text { http://dx.doi.org/10.18775/jibrm.1849- }} \\
\text { 8558.2015.45.3001 }\end{array}$ & \multirow[t]{2}{*}{$\begin{array}{l}\text { The primary objective of this research is to analyze investment capability of various Joint Stock } \\
\text { Companies (JSC) in the territory of the Uzbekistan Republic. It includes current economic } \\
\text { development of the Republic of Uzbekistan. Also, this research analyzes important priority of } \\
\text { corporations in Uzbekistan which are following: private and public enterprises, corporate } \\
\text { organizations and government organizations and corporations itself. Moreover, evaluates each } \\
\text { organization briefly and assesses their role in developing economic situation in Uzbekistan. }\end{array}$} \\
\hline $\begin{array}{l}\text { Keywords: } \\
\text { Joint Stock Company, Investment, Economic } \\
\text { Development, Market Capability }\end{array}$ & \\
\hline
\end{tabular}

\section{Introduction}

At the meeting of the Cabinet of Ministers dedicated to the report of the First President of the Republic of Uzbekistan Islam Karimov on the outcomes of socio-economic development of the country in 2014 and the most important priorities of the economic program for 2015 the following measures were taken: "In 2015, implementation of major structural changes in our economy, wide access to private property and private entrepreneurship through the continuation of modernization and diversification processes - is our priority". The fourth priority in Corporate Governance is the system of principles and approaches to the processes of production, foreign trade and the introduction of modern international corporate governance standards in investment processes.

It is well known that on January 23, 2015 at the joint session of the Legislative Chamber and the Senate of the Oliy Majlis of the Republic of Uzbekistan, a short-term and long-term Action Plan of the Cabinet of Ministers of the Republic of Uzbekistan was presented. The following strategic objectives were identified and substantiated by the President of the Republic of Uzbekistan at the session of the Cabinet of Ministers of January 16, 2015 are following:
- enhancing the competitiveness of the economy through expansion and deepening of structural reforms, modernization and active diversification of leading industries, the broad introduction of information and communication technologies, strengthening macroeconomic stability;

- elimination of all obstacles and restrictions in the way of further development of private property and private entrepreneurship and give full freedom to the development of this sphere;

- critical evaluation over government's participation in economy, restrict its authority to strategic and economic based level;

- transforming the principles and approaches in corporate governance system, as well as adopting international modern standards in corporate management of manufacture, foreign economic relationships and investment processes;

- intensification of local production and enhancement of inter-sectoral industrial cooperation;

- bringing current infrastructure, first of all, the creation of information and communication systems, road-transport and engineering-communication construction to a new level; 
- providing employment to population, in the first place, creating conditions to employ graduates of professional colleges and universities.

In order to implement the priority tasks of reducing the role of the state in the economy, the State Property Privatization Program was formed in 2015-2016. The program was approved by the Decree of the President of the Republic of Uzbekistan "On Measures to Increase the Share and Importance of Private Property in the Economy" of April 28, 2015, No 2340. This Program implies the following:

- $\quad$ liquidation of more than 660 state-owned enterprises that are not fully engaged and transferring them to new private ownership;

- a full sale of state-owned companies at 360 nonstrategic entities;

- sale of more than 400 unused state property at "zero" value. This, in turn, will allow attracting strategic foreign investors and modern technologies in the short run;

- $\quad$ reducing the share of state-owned companies to 51 percent in 203 enterprises through the sale of additional shares that is worth 450 billion sums to private investors.

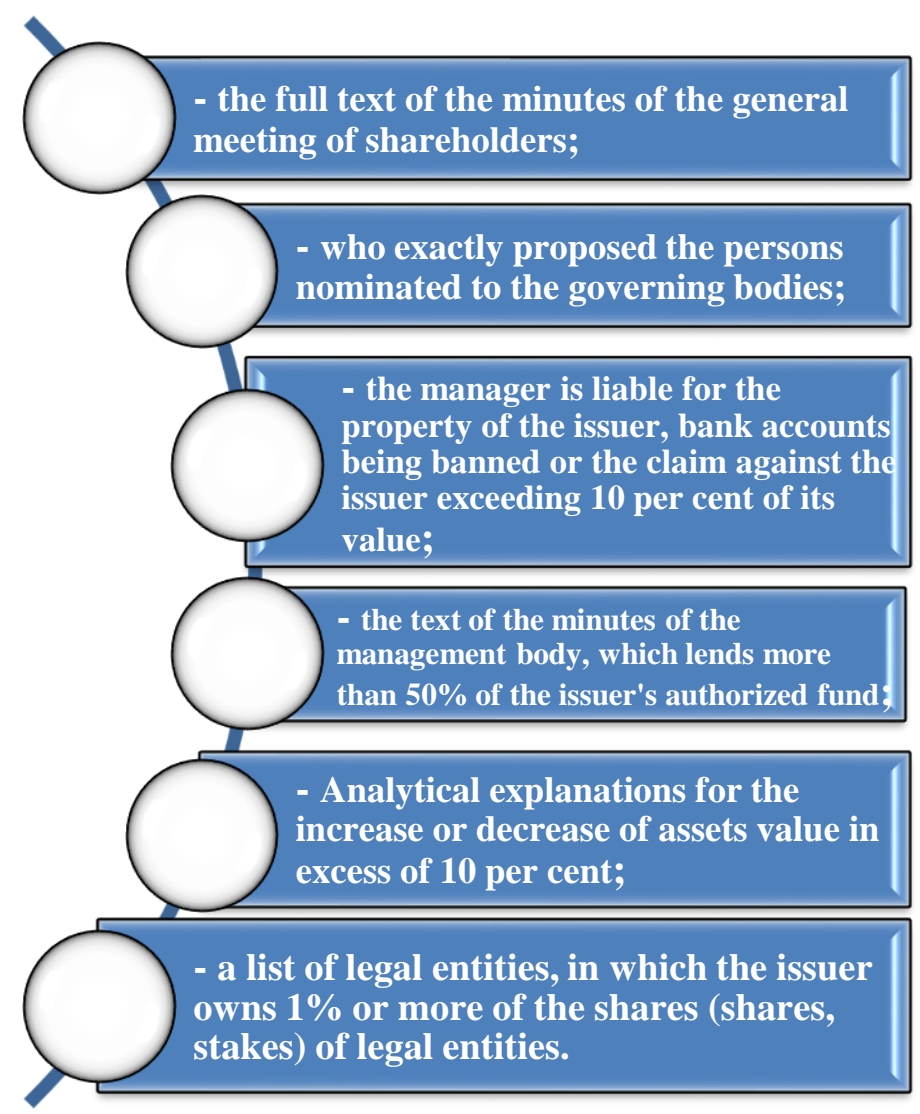

Figure 1: Useful information on corporate web sites
Measures aimed at increasing the effectiveness of corporate governance in Uzbekistan are primarily focused on further democratization of property relations and, in particular, the provision of state-owned property to the private sector on the basis of market law. At the moment, regular work is carried out on the sale of state-owned assets, at zero redemption value and increase of their efficiency, with the condition of investing.

The privatization of state-owned assets, first and foremost, has been set on sale to foreign investors and created favorable conditions for it. For example, 506 property complexes were sold on a competitive basis to new owners with a zero redemption value. It is worth mentioning that these investors have pledged to invest about 1 trillion sums and 40 million US dollars and create about 22,000 new jobs.

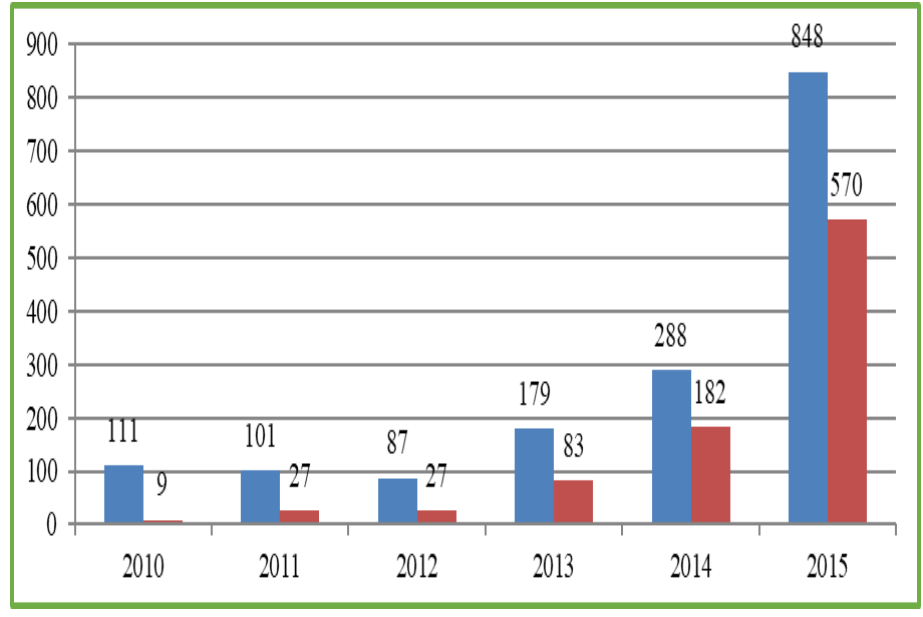

Total number of privatized state-owned assets

The number of state-owned assets sold at zero redemption value

Figure 2. Dynamics of Sale of State Property

It should be noted that, as a result of the implementation of practical measures on the privatization of state-owned property, there has been a noticeable change in the dynamics of sales of state-owned property in recent years (Figure 3.2.1).

The figures show that in 2015 , the total number of privatized state-owned assets was nearly eight times more than in 2010 , including the state-owned assets sold at a zero redemption value of more than 63 times. At the same time, 245 low-profit and non-operational organizations were liquidated.

353 state-owned property, which is in the privatization program, unused and uncompleted, was destroyed leaving 120 hectares of land area. Nearly 80 hectares of land were given to entrepreneurs for the construction of facilities and services. As part of the ongoing reforms in the country, it was required to introduce corporate governance and corporate management standards in large enterprises in order to increase the efficiency of government property management. Accordingly, over the 
years, several state-owned properties were to be sold to investors with the condition of investing.

They also emphasized the importance of identifying the key stages of effective management of state property by developing corporate strategies required for corporate governance. Each participant of the corporate governance must be aware of the sequence of implementation of the specific account and investment project on the effectiveness of the investment projects planned to be carried out within their interests. Corporate governance as an effective management system for large industrial enterprises - the example of JSC "O'zbekyengilsanoat". Corporate governance is an effective management system for large industrial enterprises. In the introduction of corporate governance in our country, it can be said that corporate governance, along with the positive aspects of the economy, has certain negotiation aspects, depending on the current stage of the economy's development and the principles of corporate governance. Including:

Consistency of private interests with social interests is not ensured; in most cases private-corporate interests are superior to the interests of society;

- The relatively fast and rapid development of stock markets increases the level of virtuality of their operations and the correlation between the growth of the real capital and the process of its development is gradually diminishing;

- There is a serious difference between the development of production and management processes due to the lack of mechanisms in the joint-stock companies to ensure that the processes of production investment are in place, and so on.

Considerable work is being done by the object of the research called "O'zbekYengilsanoat" JSC as the result of the ideas mentioned above. In particular, investments, including foreign investments, are being used to modernize the companies, acquire new techniques and technologies. Only in 2015.

Table 1: Economic indicators of JSC "O’zbekyengilsanoat"

\begin{tabular}{|c|c|c|c|c|c|c|c|c|c|c|c|}
\hline & 2005 & 2006 & 2007 & 2008 & 2009 & 2010 & 2011 & 2012 & 2013 & 2014 & 2015 \\
\hline 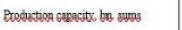 & 701,2 & 701,5 & 732 & 74,8 & 799,7 & 1169,5 & 1445,8 & 1734,9 & 2319,3 & 2852,7 & 3169,3 \\
\hline 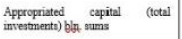 & 16,4 & 167,9 & 194,3 & 299 & 170,6 & 391 & 637,6 & 670,3 & 775,1 & 909,4 & 746.3 \\
\hline 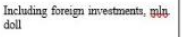 & 1079 & 79.9 & 70,9 & 136,3 & 63 & 102,4 & 17,3 & 73,9 & 80,1 & 85.6 & 39,8 \\
\hline Espart solumes $\mathrm{min}$ dell & 239,3 & 315,2 & 400,5 & 375 & 385,2 & 619,1 & 660,5 & 705,3 & 827,3 & 861,9 & 868,2 \\
\hline $\begin{array}{l}\text { Created jobs, units are shown in } \\
\text { numbers }\end{array}$ & & & & & 46410 & 50339 & 56759 & 56338 & 53095 & 46614 & 32666 \\
\hline 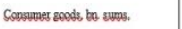 & 138,3 & 140,9 & 159,5 & 1629 & 173 & 250.9 & 418,2 & 607,2 & 857,3 & 1144,1 & 1329,1 \\
\hline 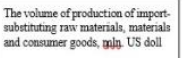 & 1,6 & 1,84 & 1.87 & 1.9 & 9,6 & 20,6 & 10,2 & 17,6 & 28,4 & 7,8 & 5,9 \\
\hline Benefte be & 2,3 & 4,7 & 4,2 & 4.5 & 4,2 & 4,4 & 3,2 & 4,7 & 4,9 & 5,1 & 4,6 \\
\hline 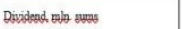 & & 10 & . & & 1,8 & 9 & 42,5 & 10,6 & 31,1 & 134,7 & 57,5 \\
\hline Starting (recortery) of fixed assets & 1499,6 & 2056,9 & 259,7 & 3506,7 & 5554,4 & 7421,3 & 9348,4 & 17835,4 & 22211,7 & 28131,2 & 3463 \\
\hline
\end{tabular}

Investments in 746.3 billion sums were allocated and from the total amount of fundsamount, 39.8 million sums were used on foreign investments.

According to the data of the Table, during the period from 2005 to 2015 JSC "O'zbekyengilsanoat" has invested 16347.7 billion soums in the production, which has been growing mainly for years. Besides, 5117.9 billion soums are invested, from which $1011.1 \mathrm{mln}$. USD is the share of direct foreign investments. During the period under review, the company created 34,2221 jobs.

The total amount of exported products was $\$ 6,257.5$ million, and the import-substituting raw materials, materials, and consumer goods, equivalent to the US \$ 107.31 million were produced. In corporate governance, $297.2 \mathrm{mln}$. dividends were distributed to the population, which is the key interest of shareholders.

For the purpose of the research, JSC "O'zbekyengilsanoat" paid attention to the following in the development of scientific recommendations on increasing the effectiveness of corporate governance in effective attraction of investments.

As noted above, sustainable and balanced development of the industry will be ensured thanks to consistent economic growth and a strong position in the world market of light industry, and the well-being of the population will be further enhanced. For this purpose, it is necessary to solve such important issues as investment attractiveness in the sector, modernization of company production, technical and technological renewal, increase of export-oriented products, improvement of management system. The economic content and features of the investment strategy in joint-stock companies are as follows:

First of all, studying the dynamics of attracting investment funds aimed at the competitive edge of the network; then it is important to analyze the impact of investment funds on the increase in fixed assets, which, in turn, affects the growth of production capacity. The investment process has a direct impact on the number of employees. On the other hand, all payments depend on the volume of production of import-substituting products in the total volume of production, in particular for domestic consumption and production for export. The end result is the amount of profit, its dividend fund and distribution to other funds.

Therefore, an analysis of the impact of attracted investment on the volume of production and the changes over the years has been implemented. For this, the dynamics of 2005-2015 has been addressed. The use of correlation and regression analysis to analyze the effects of this 11-year investment dynamics will help clarify the situation and make strategic decisions.

At the same time, eight factors were selected for the production volume, which was the final indicator of the functional relationship study. The density of each indicator with the resulting indicator was expressed by the coefficient of detection (R2). Correct linear and exponential properties were used in determining determinant coefficients. It is possible to estimate not only the determinant coefficient but also the coefficient of 
elasticity on the basis of the formula. This is because the coefficient to the linear function argument can be the elastic factor. This also allows evaluating the effectiveness of the factor and the resulting indicators. (2)

Table 2: Functions of expressing the sensitivity of factors to production volume at the SJSC "O'zbekyengilsanoat"

\begin{tabular}{|c|c|c|c|c|}
\hline \multirow[t]{4}{*}{ Name of factor identifier } & \multicolumn{4}{|c|}{ Name of result indicator } \\
\hline & \multicolumn{4}{|c|}{ Production capacity, bn sums } \\
\hline & \multicolumn{2}{|l|}{ Linear function } & \multicolumn{2}{|c|}{ Exponential function } \\
\hline & $Y=:$ & $\mathrm{R}^{2}$ & $\mathrm{Y}=:$ & $\mathrm{R}^{2}$ \\
\hline The volume of assimilated investments & $80,614 \mathrm{x}-18,418$ & 0,8705 & $116,19 e^{0,1969 x}$ & 0,8665 \\
\hline Foreign investments & $-2,7873 x+108,64$ & 0,0644 & $110,09 \mathrm{e}^{-0,042 x}$ & 0,124 \\
\hline Base value of Funds & $3276,9 \mathrm{x}-7424,4$ & 0,8801 & $1029,5 \mathrm{e}^{0,3300 \mathrm{x}}$ & 0,9919 \\
\hline Consumer goods & $119,84 x-230,07$ & 0,8309 & $73,082 e^{0,256 \pi x}$ & 0,9286 \\
\hline Created jobs & $-1869,5 x+56367$ & 0,2377 & $57816 \mathrm{e}^{-0,046 x}$ & 0,2681 \\
\hline Import substitution & $1,4266 x+1,1956$ & 0,2803 & $1,5776 \mathrm{e}^{0,2271 \mathrm{x}}$ & 0,4937 \\
\hline Export & $68,615 x+157,18$ & 0,9512 & $237,25 \mathrm{e}^{0,1313 \mathrm{x}}$ & 0,9336 \\
\hline Revenue & $0,1327 x+3,4582$ & 0,2906 & $3,3351 \mathrm{e}^{0,037 \mathrm{x}}$ & 0,28 \\
\hline
\end{tabular}

In the functions mentioned above, the demand for additional personnel in the conditions of investments is low. The introduction of modern high technologies also reduces the demand for additional workforce. For example, according to Table 3.2.2, the growth in the number of investment funds has led to a decline in jobs. Accordingly, there is a high correlation with the growth of production volumes, as well as linear functions related to investments, exports, consumer goods production and value of fixed assets Foreign investment and created jobs are in reverse proportion to the dynamics of production volumes, which is a sign of the need to increase responsiveness in the development of investment programs. The level of import substitution and export growth in the "O’zbekyengilsanoat" JSC system also demonstrates a serious direct correlation. However, it is noteworthy that in recent years, the density of communication with the dynamics of the volume of foreign investments $(\mathrm{R} 2=0.0644)$ is very low. The results of the analysis of the density of indicators were reflected in Table 3.2.3. According to the data of the table, four of the eight selected indicators have high association density and proper proportionality. Also, the average density of indicators can be calculated as the sum of the output and the volume of import-substituting products.

Table 3 Analysis of the density of factors affecting the volume of production

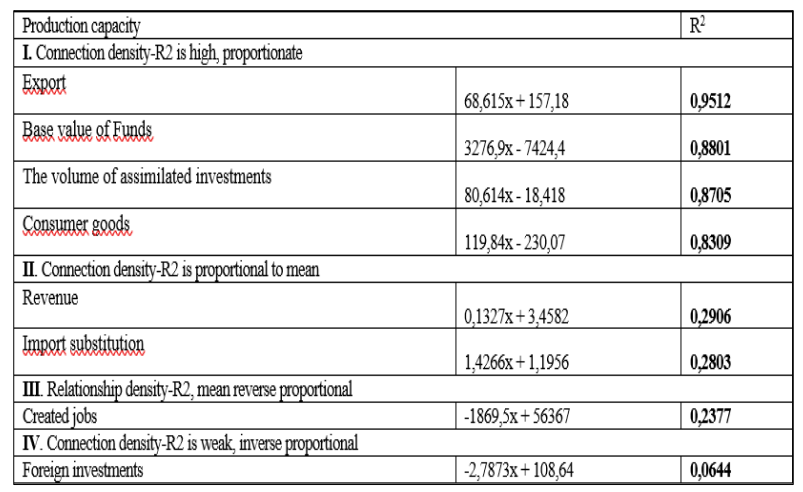

An extensive approach to the development of "O'zbekyengilsanoat" JSC, i.e., the tendency to attract investments in the traditional way, is expected to decline the impact on the development of production indicators. It is essential to focus on an intensive approach to address this situation. In particular, the importance of increasing the utilization rate of the attraction of additional investments is illustrated by the following comparisons. Based on the linear function value of the $\mathrm{Y}=80,614 \mathrm{x}-18,418$, the $\mathrm{R} 2=0,8801$ determining coefficient for the investment $(\mathrm{X})$ of the production capacity (Y), the forecasted output volume in 2017 will amount to 4207,17 billion USD. It is necessary to attract investment funds in the amount of UZS 1498.47 billion to increase by $18 \%$. If to increase the production volume forecasted for 2017, export volume will reach $1307 \mathrm{mln}$. US dollars.

Table 4: Forecast of dynamics of economic indicators in JSC "O’zbekyengilsanoat"

\begin{tabular}{|l|l|l|l|l|l|}
\hline Indicators & $\mathbf{R}^{2}$ & $\begin{array}{l}\text { Elasticity } \\
\text { coefficient }\end{array}$ & $\begin{array}{l}\text { Year 20162017 Year } \\
\text { (prognosis) }\end{array}$ & $\begin{array}{l}\text { Change, } \\
\text { (prognosis) }\end{array}$ & percent \\
\hline Production capacity & & & $\mathbf{3 5 4 2 , 0 0}$ & $\mathbf{4 2 0 7 , 1 7}$ & $\mathbf{1 1 8 , 8}$ \\
\hline $\begin{array}{l}\text { Volume of assimilated investments, } \mathrm{b}(\mathrm{n} . \\
\text { sums }\end{array}$ & 0,8705 & 80,61 & 1230,91 & 1498,47 & 121,7 \\
\hline Foreign investments, mln. USD & 0,0644 & 2,79 & 75,19 & 72,41 & 96,3 \\
\hline Cost of Funds, Bld. sums & 0,8801 & 3276,9 & 54395,05 & 75707,20 & 139,2 \\
\hline Consumer goods, bn. sums & 0,8309 & 119,84 & 1590,78 & 2056,34 & 129,3 \\
\hline Exports, mln. USD & 0,9512 & 68,62 & 1146,78 & 1307,69 & 114,0 \\
\hline \hline
\end{tabular}

The forecast parameters for 2017 are calculated on the basis of the linear functions of the highest concentration density of the selected indicators (Table 3).

According to the forecast analysis, the increase in production by $118.8 \%$ is expected to achieve significant positive shifts in the dynamics of the indicators, which are the other factors of high concentration density. At the same time, it was estimated that the development of investments, the value of fixed assets and the volumes of consumer goods in terms of production dynamics would be high.

However, it is expected to fall behind in the area of increasing the efficiency of foreign investment. In general, according to the 16 functions of two types of 8 indicators, economic analysis of determinability and elasticity coefficients, the "Uzbekyengilsanoat" will have to focus on managing the existing capacities in determining the dynamics of investment attraction in the foreseeable future. Otherwise, the likelihood of adverse events in the network will increase. The probability of such a situation can be traced back to the function of capital productivity.

Hence, when evaluating the effectiveness of the investment process, it is not expedient that corporate governance capabilities in the system are not sufficiently efficient. Elimination of this situation will contribute to strengthening the socio-economic potential of the sector. 
In our opinion, it is necessary to strengthen the focus on equity financing through the process of modernization of corporate enterprises. Because modernization processes in many sectors are currently being implemented mainly due to domestic and foreign direct investment, this leads to an increase in the external debt of the enterprise. In the context of the market economy, businesses are constantly on the lookout for their management models. It is a continuous process, because, the firm itself and the environment in which it operates change. Many companies in developed countries spend partial organizational changes at least once a year and major reorganization - every 4-5 years. Accordingly, one of the most important measures is to create mechanisms to ensure the smooth operation of processes of modernization and diversification of production at the enterprises of light industry. According to the document, the implementation of investment strategies in joint stock companies in several stages will ensure the duration and effectiveness of investment projects. At the stage of formation of the strategic goals of investment activity in joint-stock companies, the goals of capital growth, change of the ratio of real and financial investments or an increase of profitability level are based on the general strategy of economic development. The stage of development of the most effective ways of implementing strategic goals of investment activity is the most complicated and responsible.

Issues of development of strategic directions of investment activity and development of investment resources formation strategies will be discussed. The selected strategic goals are presented to the supervisory board which is the essential part of corporate governance in the investment project and through its decisions will move to the next stage of the investment project. The selected strategic goals and investment project will be submitted to the supervisory board for the most important part of corporate governance and will be moved to the next stage of the investment project by its decision. At the stage of determining the investment strategy for the implementation phase, it is envisaged that achievement of specific objectives and performance of tasks will be ensured by external synchronization to the situation in the investment market and the internal synchronization of achievement of different goals within the company.

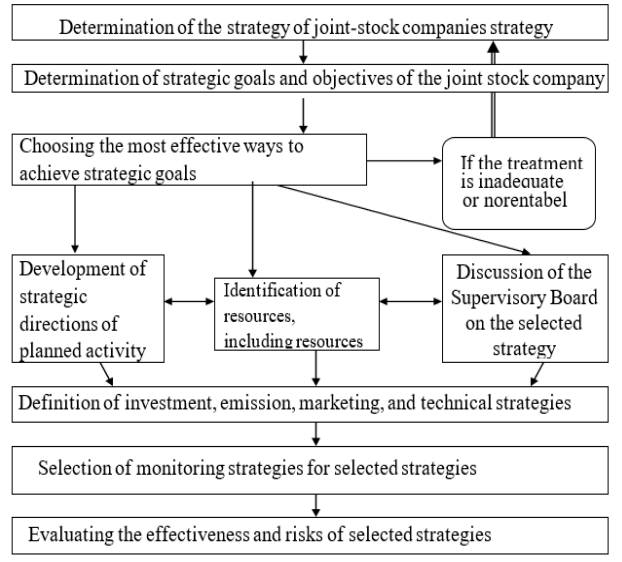

Figure 3: Key Stages of Investment Strategy Formation in Joint Stock Companies
According to the document, the implementation of investment strategies in joint stock companies in several stages will ensure the duration and effectiveness of investment projects.

At the stage of formation of the strategic goals of investment activity in joint-stock companies, the goals of capital growth, change of the ratio of real and financial investments or an increase of profitability level are based on the general strategy of economic development.

- The stage of development of the most effective ways of implementing strategic goals of investment activity is the most complicated and responsible.

- Issues of development of strategic directions of investment activity and development of investment resources formation strategies will be discussed.

The selected strategic goals are presented to the supervisory board which is the essential part of corporate governance in the investment project and through its decisions will move to the next stage of the investment project.

The selected strategic goals and investment project will be submitted to the supervisory board for the most important part of corporate governance and will be moved to the next stage of the investment project by its decision.

At the stage of determining the investment strategy for the implementation phase, it is envisaged that achievement of specific objectives and performance of tasks will be ensured by external synchronization to the situation in the investment market and the internal synchronization of achievement of different goals within the company.

The stage of evaluation of the developed investment strategy is based on the following criteria:

1) Harmonization of the investment strategy of the enterprise with the general strategy of economic development;

2) internal equilibrium of the investment strategy, i.e., the consistency of goals;

3) compliance of the investment strategy with the external environment;

4) opportunity to implement an investment strategy based on existing resource potential;

5) An acceptable level of risk associated with the implementation of an investment strategy;

6) The effectiveness of the investment strategy. At first, the economic impact of their implementation will be assessed.

As a result of the development of an investment strategy in joint-stock companies, effective management decisions are made, and specific targets for the company's development are projected, which means that activities that are likely to result in a single outcome are projected. In particular, the investment design process can lead to better results after the overall investment strategy and prioritized targets are identified. Then it can be proven that your investment activity is based on the 
most available and affordable opportunities. In our opinion, the sale of state-owned shares of joint-stock companies in our country and the implementation of major investment projects on the basis of strategic plans and organization of corporate governance mechanisms will ensure the effectiveness of investment projects.

\section{Conclusion}

As a result of the development of an investment strategy in joint-stock companies, effective management decisions are made, and specific targets for the company's development are projected, which means that activities that are likely to result in a single outcome are projected. In particular, the investment design process can lead to better results after the overall investment strategy and prioritized targets are identified. Then it can be proven that your investment activity is based on the most available and affordable opportunities.

In our opinion, the sale of state-owned shares of joint-stock companies in our country and the implementation of major investment projects on the basis of strategic plans and organization of corporate governance mechanisms will ensure the effectiveness of investment projects.

We propose to introduce the following investment strategies in the formation of corporate governance mechanisms in investment projects in the country, where investment is sold, and large enterprises are newly established

\section{References:}

- Ashurbekov, R., \& Anbari, F. T. THE CURRENT STATE, PROBLEMS AND PERSPECTIVES OF DEVELOPMENT OF MODERN PROJECT MANAGEMENT EDUCATION IN UZBEKISTAN. ALATOO ACADEMIC STUDIES, 21.

- Ashurov, Z. (2014). The Corporate Governance in Uzbekistan: A Special Focus on the Board's Supervisory Role Compared with German Practice. International Scientific Journal" Corporate Board: role, duties and composition, 10(3), 77-96. $\underline{\text { Crossref }}$

- Ashurov, Z., \& Bibutova, S. (2012). The Specificities of Organizational and Economic Development of Corporate Governance in the Chemical Industry. Birja Ekspert'Journal, (10-11), 3-7.

- Barca, F., \& Becht, M. (2002). The control of corporate Europe. Oxford University Press. Crossref

- Bonga, W. G., Sithole, R., \& Shenje, T. (2015). Export sector contribution to economic growth in Zimbabwe: A causality analysis. The International Journal of Business \& Management, 3(10).

- Claessens, S. (2006). Corporate governance and development. The World bank research observer, 21(1), 91122. Crossref

- Core, J. E., Holthausen, R. W., \& Larcker, D. F. (1999). Corporate governance, chief executive officer compensation, and firm performance. Journal of financial economics, 51(3), 371-406. Crossref
- Dabor, E. L., \& Adeyemi, S. B. (2009). Corporate governance and the credibility of financial statements in Nigeria. Journal of Business Systems, Governance and Ethics, 4(1), 13-24. Crossref

- Fan, P. S. (2004). Review of literature \& empirical research on corporate governance. Research paper/Monetary Authority of Singapore.

- Jesover, F., \& Kirkpatrick, G. (2005). The revised OECD principles of corporate governance and their relevance to non- OECD countries. Corporate Governance: An International Review, 13(2), 127-136. $\underline{\text { Crossref }}$

- Karimov, I. A. (2010). The Concept of the Further Deepening of the Democratic Reforms and the Formation of the Civil Society in the Country. Uzbekistan, Tashkent.

- La Porta, R., Lopez-de-Silanes, F., Shleifer, A., \& Vishny, R. (2000). Investor protection and corporate governance. Journal of financial economics, 58(1-2), 3-27. Crossref

- Onuorah, A., \& Friday, I. O. (2016). Corporate Governance and Financial Reporting Quality in Selected Nigerian Company. International Journal of Management Science and Business Administration, 2(3), 7-16. Crossref

- Rahman, R. A., \& Haniffa, R. M. (2005). The effect of role duality on corporate performance in Malaysia. Corporate ownership and control, 2(2), 40-47. Crossref

- Shukurov, S., Maitah, M., \& Smutka, L. (2016). The impact of privatization on economic growth: The case of Uzbekistan. International Journal of Economics and Financial Issues, 6(3), 948-957.

- Siebens, H. (2002). Concepts and working instruments for corporate governance. Journal of Business Ethics, 39(1-2), 109-116. Crossref

- Suvanova, K., Kang, H. G., \& Lee, C. (2016). Securities market development in a transition economy: Uzbekistan's experience. Актуальні проблеми економіки, (10), 335 347.

- Suyunov, A., Mirkasimov, B., \& Karimov, K. (2018). RESEARCH AND DEVELOPMENT REFORM: THE CASE OF KAZAKHSTAN AND UZBEKISTAN. International Journal of Civil Service Reform and Practice, 3(2).

- Suyunov, A., Mirkasimov, B., \& Karimov, K. (2018). RESEARCH AND DEVELOPMENT REFORM: THE CASE OF KAZAKHSTAN AND UZBEKISTAN. International Journal of Civil Service Reform and Practice, 3(2).

- Tara, S., \& Sadri, S. (2015). Corporate Governance and Risk Management: An Indian Perspective. International Journal of Management Science and Business Administration, 1(9), 33-39. Crossref

- Troschke, M., \& Zeitler, A. (2006). Privatisation and corporate governance in Kazakhstan and Uzbekistan: insights from a corporate survey in food and light industries (No. 259). Arbeiten aus dem Osteuropa-Institut München 